\title{
An assessment of R\&D tax credits and their role towards innovation within Irish industry
}

Research Article

\author{
James Kennedy" and Frank Barry \\ Trinity Business School, Trinity College Dublin, Ireland
}

\begin{abstract}
The Irish Government has identified research and development (R\&D) and innovation as among the key pillars of growth within the economy. To achieve this growth, R\&D tax incentives, which are adopted in advanced economies, are set into policy to encourage firms to innovate, thus, making companies more competitive and productive. One of the key enablers to driving R\&D is a well-designed, competitive and sustainable tax policy to support the activity. However, evidence on the effectiveness of R\&D tax incentives for innovation is largely anecdotal and the influence of innovation on firm-level taxation is still underexplored, in terms of and empirical examination. This paper sets out to review the recent trends and views of industry regarding R\&D tax credits.
\end{abstract}

Keywords: $R \& D$ tax credits; innovation; $B E R D$

(C) Sciendo

\section{INTRODUCTION}

The goal of the research and development (R\&D) tax credit is to encourage R\&D investment by indigenous and foreign-owned firms of all sizes by rewarding qualified research. This tax mechanism offsets against tax liability, because the credits can help companies to increase their cash flow and earnings per share, reduce their effective tax rate, hire more staff, develop new products, and finance other business objectives. R\&D tax incentive schemes are widely adopted in advanced economies to promote innovation thus making companies more competitive and productive.

In terms of R\&D and innovation, the main justification for public intervention resides in the lack of incentives for private agents to invest, as well as their lack of means (Martin and Scott, 2000). The Organisation for Economic Co-operation and Development (OECD) recognises the fundamental importance of R\&D, as defined in its Frascati programme and the scale of opportunity that investment in innovation can bring (Irish Tax Institute, 2015). It is well known that R\&D tax policies are written to encourage firms to innovation - a crucial driver of business growth. However, evidence on the effectiveness of tax benefits for innovation is largely anecdotal and the influence of innovation on firm-level taxation is still underexplored, in terms of empirical examination (Gao, et al., 2016).

Economic theory provides a strong justification for government support for R\&D, including subsidies and incentives for business research. Without such support, companies are likely to underinvest in research (from the standpoint of the economy), because the results of R\&D cannot be fully appropriated by the investing firm (Tyson and Linden, 2012). Economists and other social scientists have demonstrated that the R\&D activities of private firms generate widespread benefits enjoyed by consumers and society at large. Thus, the overall economic value to society often exceeds the economic benefits enjoyed by innovating firms, through their research efforts. This excess of the social rate of return over the private rate of return enjoyed by innovating firms is described by economists as a positive externality or spillover.

Knowledge spillovers are likely to result from basic research, but they are also produced by applied research and technology development (Jaffe, 1996). However, despite their best efforts and the benefits of patent protection, firms cannot prevent the knowledge gained through their R\&D from leaking out, or spilling over, to other firms. 
These spillovers occur, for example, as researchers exchange ideas at professional meetings and as they move from firm to firm. More generally, discovery in one firm can trigger new avenues of research, inspire new research projects, or find new applications in other firms (Lester, 2012).

While the market function is to reward commercialisation after intellectual property (IP) development, market failure may still exist, because competitors may reap the benefits of innovation without incurring the costs of development. Despite the presence of R\&D tax benefits, one firm's efforts in bringing an innovation to market can create a spillover effect to firms that did not commit the investment in R\&D (Atkinson and Andes, 2011). Apple's iPad offers an example: despite being protected by patents in the United States (US) and Europe, once the device became popular, similar competing tablets quickly emerged, suggesting that Apple was unable to capture anywhere near all of the returns from its innovation (Jones et al., 2016).

However, innovation is essentially about bringing new ideas to the market. If the purpose of R\&D tax incentives is to foster innovation, it is relevant to consider not only what type of R\&D costs are eligible, but also whether R\&D is primarily intended for true innovation or for learning from other firms (Straathof et al., 2014). The study conducted by Straathof et al. (2014) found that countries that introduced the R\&D tax incentives at different points in time shaped them in various ways. Even for such a generic policy instrument, the specific design, type and number of R\&D tax incentives differ substantially across countries. These differences can be divided into three main categories:

1. Scope of the policy, including the type of R\&D tax incentive and costs covered.

2. Targeting of specific groups of firms, per size, age, region, etc.

3. Organisation, including administrative practices and generosity.

The amount of additional R\&D induced by government support is a key evaluation consideration: all else being equal, the higher the responsiveness to a subsidy, the higher the net benefit (Lester, 2012). More than 20 OECD countries currently support private R\&D investments through this type of scheme, including advanced countries and developing economies (non-OECD), such as Brazil, India, China and South Africa (OECD, 2010).

R\&D tax incentives, which are tax deductions that firms can claim if they are involved in R\&D activities, thus provide companies with an incentive to increase their innovation efforts. Tax credits are typically directed at all firms in the economy and hence allow private agents to decide what type of project to apply for (Castellacci and Lie, 2015). Tax incentives are a market-orientated means of delivering an increase in private R\&D expenditure, also allowing firms to avail of the support offered by the credit flexibility to respond to market demand. Tax credits allow expenditure to be directed by market-aware firms, rather than by a centralised authority. While the flexibility of such credits to respond to market demand is useful, it also creates an uncertain and unlimited demand on the Exchequer. Their operation varies between countries but in general, companies can deduct a percentage of eligible R\&D expenditure from corporation tax liability (Department of Finance, 2013).

The main economic rationale for using any of these tools rests on the notion that market failures reduce or may even deter private R\&D investment. These failures derive mostly from knowledge spillovers and from asymmetric information. This can lead to difficulties is appropriability, through imitation by rivals; asymmetric information between investors and inventors may result in financing constraints (Busom et al., 2014). Although tax credits may provide a stimulus to overall R\&D activity, some authors have stressed that they are less suitable than grants to address the sources of market failure, that is, due to the lack of capital to be invested (Czarnitzki et al., 2011). In addition, they are likely to encourage firms to undertake R\&D activities resulting in short-term revenues, rather than projects with high rates of social return or long-term exploratory activities (Hall and Van Reenen, 2000). Although there is substantial evidence that R\&D tax incentives do increase the amount of R\&D investment, there is considerable variation in estimating the intensity of the effects (Evers, 2014).

To coincide with the global studies, the 2016 Department of Finance report on the evaluation of the R\&D tax credit has calculated that for each euro in foregone revenue, an additional $€ 2.40$ is generated in R\&D. This suggests that the policy is achieving its aim of increasing R\&D, but with considerable deadweight. Fundamentally, the calculations have shown that roughly $40 \%$ of the R\&D observed over the period would have occurred anyway, that is, in the absence of the tax credit, while $60 \%$ of the R\&D observed was due to the tax credit, namely, additional R\&D. However, the report does acknowledge that until further work has been undertaken on R\&D grants, preferably using a non-self-assessment method, no conclusion can be made on whether the tax credit with $40 \%$ deadweight is more efficient than R\&D grants (Department of Finance, 2016).

From an Irish context, the R\&D tax credit administered by the Irish Revenue Commissioners is open to all companies in Ireland that undertake qualifying R\&D activities in Ireland, or within the European Economic Area. During the time frame of this work (pre 2019), the Qualifying R\&D expenditure generated a $25 \%$ tax credit to offset 
against corporate taxes. Please note, since this survey and work was assessed from 2017 to 2018 and the time the paper was under review, changes were made in Budget 2020 regarding R\&D Tax credits namely an increase from $25 \%$ to $30 \%$ for micro and small companies.

To achieve such a policy for Ireland, particularly in a base erosion and profit shifting (BEPS) environment, it is important to be clear about the nature of the innovation activities that are carried out in Ireland - both by multinationals and by domestic-based companies (Irish Tax Institute, 2015). A recent Irish Business and Employers Confederation (IBEC) survey (IBEC, 2013) involving 247 firms showed that participation in the tax credit scheme leads to improvements in the R\&D process in firms. Almost two-thirds of firms saw an improvement in how they planned R\&D activities; $70 \%$ improved on the recording of their activities; and $69 \%$ improved in the way they retained their R\&D-related documentation. Also, the scheme is regarded by most firms as a key element in their decision to invest in Ireland. In several cases, it was noted that without the scheme, the R\&D function would be under threat within the country. SMEs and multinationals confirmed that it was an essential part of increasing their productivity, improving offerings for customers, and increasing employment (IBEC, 2013).

With this in mind, the premise of the current work is to look at business expenditure on research and development (BERD), via published data from the Central Statistics Office (CSO) and government agencies, and to consider how the R\&D tax credit mechanism has grown with the increase in BERD. In parallel, the views from the survey responders are assessed to reflect the challenges and merits of the R\&D tax credit scheme.

\section{METHOD}

This study used several methods in its approach, such as desk research, consultation via a survey, and an interview programme. The desk research reviewed and assessed recent quantitative data from government departments and the CSO, as well as reviewing the relevant national and international literature. Between January and June 2017, interviews with the Department of Business, Enterprise and Innovation (DJEI) and IBEC took place, after which a questionnaire was developed. Subsequently, a survey of Irish firms was conducted, regarding their experience, knowledge and awareness of R\&D tax credits. Consultation and guidance were provided by Professor Frank Barry, the DJEI and IBEC.

The research strategy taken used the archival research approach, in order to complement the survey response. This study involved 122 respondents from 438 companies, which gave a $28 \%$ response rate. Of these respondents, $38 \%$ were from CEO's, which gives validation to the relevance of this work and its timing. Unless otherwise stated, the values presented below are the percentage values associated with the 122 responses.

\section{RESULTS}

As a background to this paper, and to give the reader an appreciation of the level of BERD expenditure, the findings from a 2017 CSO study (CSO, 2017) on business expenditure on R\&D between 2015 and 2016 is presented in Table 1. The CSO survey showed that more than $€ 2.2 \mathrm{bn}$ was spent on R\&D activities by enterprises in Ireland in 2015 , with $€ 2$.3bn estimated for 2016. A comparison between the 2013-2014 and 2015-2016 CSO findings is also reviewed in Table 1.

As with most R\&D projects, there is an associated risk, hence the cost, and to reduce such risk and promote innovation, government incentives such as R\&D tax credits are a mechanism by which risky projects can be justified. However, in practice, they can also be used to reduce the corporation tax paid by established companies or to generate cash flow back into smaller or start-up companies. Therefore, the purpose of this finding was to evaluate the trends associated with the R\&D tax credits, in order to gain a strategic understanding of the environment. Specific data was collated from several official sources: the information is presented in Table 2 and selected data is graphically presented in Figure1.

When asked if there was an awareness of the R\&D tax credit within their organisation, 95\% of those surveyed replied 'Yes'. It should be noted that there were 101 responses to this question. A breakdown between company groupings is presented in Table 3.

Leading on from this question, companies were asked if they use or continue to use R\&D tax credits. The, results including a breakdown of the company size, are presented in Table 4. 
Table 1. Comparison between 2013-2014 and 2015-2016 BERD CSO findings

\begin{tabular}{|c|c|}
\hline 2013-2014 & 2015-2016 \\
\hline $\begin{array}{l}\text { - Enterprises that employ } 250 \text { persons or more had the greatest } \\
\text { share of R\&D expenditure in } 2013 \text {, with just under } 50 \% \text { of all actual } \\
\text { expenditure. }\end{array}$ & $\begin{array}{l}\text { - Enterprises that employ } 250 \text { persons or more had the greatest } \\
\text { share of R\&D expenditure in } 2015 \text {, with just under } 55 \% \text { of all actual } \\
\text { expenditure. }\end{array}$ \\
\hline $\begin{array}{l}\text { - Medium-sized enterprises employing between } 50 \text { and } 249 \text { persons } \\
\text { spent } € 576 \mathrm{~m} \text { in the same period, which represents more than } 28 \% \text { of } \\
\text { total spend. }\end{array}$ & $\begin{array}{l}\text { - Medium-sized enterprises employing between } 50 \text { and } 249 \text { persons } \\
\text { spent } € 50 \mathrm{~m} \text { in the same period, which represents more than } 23 \% \text { of } \\
\text { total spend. }\end{array}$ \\
\hline $\begin{array}{l}\text { - Small enterprises with fewer than } 50 \text { persons engaged spent almost } \\
€ 445 \mathrm{~m} \text { on R\&D in } 2013 \text {, which accounted for } 22 \% \text { of the spend. }\end{array}$ & $\begin{array}{l}\text { - Small enterprises with fewer than } 50 \text { persons engaged spent almost } \\
€ 502 m \text { on } R \& D \text { in } 2015 \text {, which accounted for } 22 \% \text { of the spend. }\end{array}$ \\
\hline $\begin{array}{l}\text { - Over } € 1.2 \text { bn was spent on labour costs, which accounted for } 61 \% \text { of } \\
\text { all R\&D expenditure. }\end{array}$ & $\begin{array}{l}\text { - Over } € 1.3 b n \text { was spent on labour costs, which accounted for } 61 \% \text { of } \\
\text { all R\&D expenditure. }\end{array}$ \\
\hline $\begin{array}{l}\text { - Current costs, which include materials, supplies, equipment and } \\
\text { overheads associated with R\&D, had an associated cost of nearly } \\
€ 636 \mathrm{~m} \text {, which accounted for } 31 \% \text { of total expenditure. }\end{array}$ & $\begin{array}{l}\text { - Current costs, which include materials, supplies, equipment and } \\
\text { overheads associated with R\&D, had an associated cost of nearly } \\
€ 726 \mathrm{~m} \text {, which accounted for } 33 \% \text { of total expenditure. }\end{array}$ \\
\hline $\begin{array}{l}\text { - The remaining expenditure of } € 147 \mathrm{~m} \text { was accounted for by capital } \\
\text { expenditure, with just over } 50 \% \text { of capital expenditure being spent on } \\
\text { instruments and equipment acquired wholly for R\&D purposes. }\end{array}$ & $\begin{array}{l}\text { - The remaining expenditure of } € 157 m \text { was accounted for by capital } \\
\text { expenditure, with just over } 53 \% \text { of capital expenditure being spent on } \\
\text { instruments and equipment acquired wholly for R\&D purposes. }\end{array}$ \\
\hline $\begin{array}{l}\text { - R\&D spending was highest in the services sector, which accounted } \\
\text { for } 57 \% \text { of all expenditure. Spending in this sector was just under } \\
€ 1.2 b n \text { in } 2013 \text {, while the manufacturing sector spent over } € 864 \mathrm{~m} \text { on } \\
\text { R\&D. }\end{array}$ & $\begin{array}{l}\text { - R\&D spending was highest in the services sector, which accounted } \\
\text { for } 61 \% \text { of all expenditure. Spending in this sector was just under } \\
€ 1.4 \mathrm{bn} \text { in } 2015 \text {, while the manufacturing sector spent more than } € 876 \mathrm{~m} \\
\text { on R\&D. }\end{array}$ \\
\hline $\begin{array}{l}\text { - } 90 \% \text { of all R\&D expenditure was funded by enterprises' own } \\
\text { company/internal funds, while } 6 \% \text { of expenditure was funded from } \\
\text { public funds. Small enterprises were more likely to use public funds, } \\
\text { with } 9 \% \text { of funding for these enterprises attributed to public funding. }\end{array}$ & $\begin{array}{l}\text { - } 88 \% \text { of all R\&D expenditure was funded by enterprises' own } \\
\text { company/internal funds, while } 6 \% \text { of expenditure was funded from } \\
\text { public funds. Small enterprises were more likely to use public funds, } \\
\text { with } 7 \% \text { of funding for these enterprises attributed to public funding. }\end{array}$ \\
\hline $\begin{array}{l}\text { - There were nearly } 2,000 \text { enterprises engaged in R\&D activities in } \\
\text { Ireland in } 2013 \text {. More than } 74 \% \text { of all enterprises spent less than } \\
€ 500,000 \text { on } R \& D \text { activities. Just over one- sixth spent between } \\
€ 500,000 \text { and } € 2 m \text {, while only } 10 \% \text { of enterprises spent } € 2 m \text { or more } \\
\text { on R\&D activities. }\end{array}$ & $\begin{array}{l}\text { - There were nearly } 1,900 \text { enterprises engaged in R\&D activities in } \\
\text { Ireland in } 2015 \text {. More than } 73 \% \text { of all enterprises spent less than } \\
€ 500,000 \text { on R\&D activities. Just over one-sixth spent between } \\
€ 500,000 \text { and } € 2 \mathrm{~m} \text {, while only } 10 \% \text { of enterprises spent } € 2 \mathrm{~m} \text { or more } \\
\text { on R\&D activities. }\end{array}$ \\
\hline $\begin{array}{l}\text { - In } 2013 \text {, nearly } 1,500 \text { small enterprises were engaged in R\&D. They } \\
\text { accounted for } 73 \% \text { of all R\&D active enterprises compared with } \\
378 \text { medium enterprises, which accounted for } 19 \% \text { of R\&D active } \\
\text { enterprises and } 143 \text { large enterprises, which accounted for } 7 \% \text { of all } \\
\text { R\&D active enterprises. }\end{array}$ & $\begin{array}{l}\text { - In } 2015 \text {, nearly } 1,300 \text { small enterprises were engaged in R\&D. They } \\
\text { accounted for } 71 \% \text { of all R\&D active enterprises compared with } \\
386 \text { medium enterprises, which accounted for } 21 \% \text { of R\&D active } \\
\text { enterprises and } 166 \text { large enterprises, which accounted for } 9 \% \text { of all } \\
\text { R\&D active enterprises }\end{array}$ \\
\hline
\end{tabular}

Table 2. Collected data with the base year set at 2004

\begin{tabular}{ccccc}
\hline Year & $\begin{array}{c}\text { Credit paid out by } \\
\text { revenue } \mathbf{\epsilon m}^{*}\end{array}$ & $\begin{array}{c}\text { No. of company } \\
\text { claims to revenue* }\end{array}$ & $\begin{array}{c}\text { BERD } \\
\text { Łm }^{\wedge}\end{array}$ & Companies involved in R\&D \\
\hline 2004 & 70.5 & 75 & 1,210 & 1,200 \\
2009 & 216 & 900 & 1,869 & 1,282 \\
2010 & 224 & 1172 & 1,834 & - \\
2011 & 261 & 1409 & 1,757 & 1,600 \\
2012 & 282 & 1543 & 1,962 & - \\
2013 & 421 & 1576 & 2,000 \\
2014 & 553 & 1570 & 2,107 & - \\
\hline
\end{tabular}

Please note that for 2014, the full data was not available at the time of submission, but it is expected to be adjusted upwards - CSO, 2016. Where there is a blank, data was not available. Sources of information obtained from Revenue 2016, an analysis of corporate Tax Receipts in $2014-2015^{\star}-2004$ figures from Department of Finance 2013, DJEI, Forfas and CSO. 
Table 3. R\&D tax credit promotion

Do you think the R\&D tax credit has adequately been promoted?

\begin{tabular}{lcc}
\hline \hline & Yes (\%) & No (\%) \\
Start-up $[\mathrm{n}=29]$ & 34 & 31 \\
Small enterprise (<50 employees) $[\mathrm{n}=34]$ & 38 & 41 \\
SME foreign owned (50-250 employees) $[\mathrm{n}=3]$ & 33 & 33 \\
SME Irish owned (50-250 employees) $[\mathrm{n}=10]$ & 50 & 30 \\
Multinational foreign owned [n=19] & 68 & 21 \\
Multinational Irish owned $[\mathrm{n}=4]$ & 75 & 0 \\
\hline
\end{tabular}

$\mathrm{n}=$ sample size

Table 4. Claiming the credit

\begin{tabular}{lcc}
\hline Does your company claim the credit? & & \\
\hline \hline \\
Start-up [n=29] & Yes (\%) & No (\%) \\
Small enterprise (<50 employees) [n=34] & 7 & 66 \\
SME foreign owned (50-250 employees) [n=3] & 13 & 0 \\
SME Irish owned (50-250 employees) [n=10] & 33 & 80 \\
Multinational foreign owned [n=19] & 10 & 72 \\
Multinational Irish owned [n=4] & 0 & 50 \\
\hline
\end{tabular}

\section{$\mathrm{n}$ = sample size}

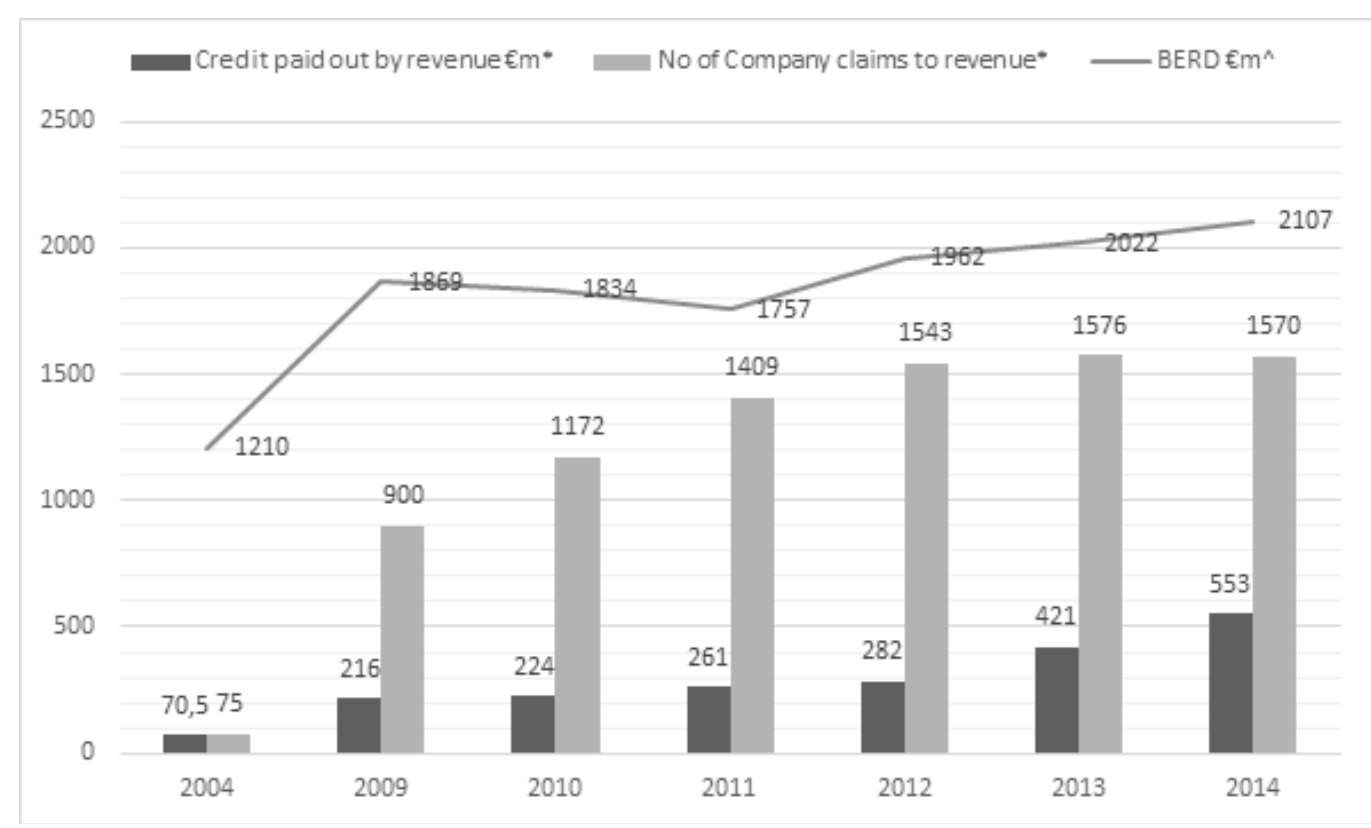

Figure 1. An overview of the main indicators associated with the R\&D tax credit. (Sources of information obtained from Revenue 2016, an analysis of corporate Tax Receipts in 2014-2015*-2004 figures from Department of Finance 2013, DJEl, Forfas and CSO) 
When asked if the R\&D tax credit has helped to create jobs within their organisation, the following findings emerged, as presented in Table 5. These findings are comparable with a study IBEC carried out in 2013, which looked at R\&D employment (see Table 6).

Table 5. Job creation because of the credit within the organisation

\begin{tabular}{|c|c|c|c|}
\hline \multicolumn{4}{|c|}{ Has the credit helped created jobs within the organisation? } \\
\hline & Not Sure(\%) & Yes (\%) & No $(\%)$ \\
\hline Total response & 21 & 35 & 44 \\
\hline \multicolumn{4}{|c|}{ Sector breakdown } \\
\hline Start-up $[n=29]$ & 14 & 17 & 69 \\
\hline Small enterprise $(<50$ employees) $[\mathrm{n}=34]$ & 18 & 35 & 47 \\
\hline SME foreign owned (50-250 employees) $[n=3]$ & 33 & 0 & 67 \\
\hline SME Irish owned (50 -250 employees) [ $n=10]$ & 40 & 50 & 10 \\
\hline Multinational foreign owned $[n=19]$ & 21 & 42 & 37 \\
\hline Multinational Irish owned $[n=4]$ & 25 & 75 & 0 \\
\hline
\end{tabular}

$\mathrm{n}=$ sample size

Table 6. A snapshot of R\&D related jobs (IBEC, 2014)

\begin{tabular}{|c|c|c|c|}
\hline & 2003 & 2007 & 2011 \\
\hline Total R\&D jobs & 355 & 1,129 & 2,990 \\
\hline Total R\&D tax credit related jobs & 279 & 894 & 2,523 \\
\hline Total number of employees allocating all/some of their time to R\&D & 375 & 1,270 & 3,016 \\
\hline Total number of employees & 13,558 & 24,560 & 33,898 \\
\hline Average employment growth since previous year & $8.5 \%$ & $17.4 \%$ & $10.7 \%$ \\
\hline
\end{tabular}

Table 6 shows that dedicated R\&D employment in the firms increased during the period from 355 to 2,990, while total employees using some part of their time for $R \& D$ rose to 3,016 . The difference between the two readings is likely because many companies perform R\&D in cross-functional teams, rather than having specific R\&D positions, so there are usually more people in R\&D-related jobs than dedicated R\&D jobs. Total employment in the firms increased from 13,558 in 2003 to 33,898 in 2011.

From the information presented in Tables 1 and 2, there is a noted difference between the R\&D active companies versus R\&D-active companies claiming the R\&D tax credit. As part of this work, it was important to explore the reasons why a company would not avail of a $25 \%$ rebate of qualifying R\&D expenditure. Selected views from the responders are shown in Table 7 and recommendations to improve the R\&D tax credit process from industry are presented Table 8. 
Table 7 Reasons why companies do not avail of the R\&D tax credit

\section{Administration-majority of responders gave this reason}

We claim R\&D tax credit only for some projects. In reality, we should be able to claim it for more, as the activity we are doing constitutes R\&D in the typical meaning, but not necessarily in the legislative definition. Currently, or alternatively, the burden of demonstration on this relative to the cost involved in doing so is great. The system needs to be simpler. We have a good R\&D capability. However, the scheme is not really where it needs to be to be a real incentive. Currently, it does not excite engineers, etc.

Rule changes and complexity are very onerous on small start-ups.

We don't innovate because there's a tax credit - we do it because we must.

Most companies are aware of the R\&D credits ... although a fully compliant tax return is sometimes not that readily available.

You have to pay an accountant to claim it. Not user friendly for an SME. It triggered a revenue audit as, Revenue don't like it.

R\&D tax credits provide a cash bonus to the business in general and are accounted for outside of the R\&D budget. All our R\&D investments must make financial sense on their own, and the R\&D tax credit is never a factor in decision-making around project selection or the quantum of R\&D undertaken. Therefore, the R\&D tax credit provides a bonus to companies engaged in innovation but doesn't provide an incentive to increase the amount of R\&D undertaken.

Some MNCs have done collaborative projects with us and have taken advantage of the R\&D tax credit. It was likely to have been a consideration when the company decided to carry out the research in Ireland.

R\&D tax credits are only useful for very large organisations that have the labour and financial resources to work on break-through innovation. They are not suited to SME companies that have to work largely on incremental innovation and do not have designated team members on individual projects.

$R \& D$ tax credit have been critical to $R \& D$ in Ireland and to the manufacturing jobs that have resulted from that $R \& D$.

Lack of clarity on eligibility, especially in the software development arena

Cumbersome and slow process.

Revenue appear to be taking a different stance on R\&D, don't provide good guidelines, and then challenge claims fairly aggressively.

The continual re-appraisal of the rules and guidelines by Revenue - what is accepted today may not be accepted tomorrow

There are no significant barriers except the definition of the type and quality of innovation that is to be used, e.g. incremental vs. disruptive innovation.

Some people may consider the strict timesheet approach to tracking work undertaken in R\&D to be too cumbersome ... especially if the gain is only marginal.

The "claw back" - if you inadvertently claim for something you were not entitled to, you have to pay it back promptly, plus interest.

The level of work involved to prove the work is in depth research.

The cost of processing the claim by accountants.

Writing final reports and aligning with other projects.

Technical definition of what an innovation is far too high and is based upon laboratory study only; and the administration for the scheme is too much.

Better clarity on what exactly is eligible. Accountancy firms try and complicate and cloud this in order to generate fees.

Start-ups struggle to get all the processes and software in place to track time spent, in order to claim the tax back.

Audits. 
Table 8. Industry recommendation to improve the R\&D tax credit process

Quick turnaround on decision from revenue.

Credits are paid back over a shorter period of time.

Make compliance easier for all companies. We are, by definition, a large company (currently 350 employees). However, by comparison to other players globally, we are small. We need to be mindful of competitiveness, so the cost of compliance should be reduced.

Simple structure.

Get pre-approval from Revenue on suitability of R\&D activities for receiving the tax credit.

Simplify application process and speed up approval and payments.

Reduce records and admin.

More transparency, set guidelines and parameters to operate within and audit accordingly.

Simplification of requirements.

Streamline the process. Maybe an online portal to bring together all the required information for the application.

Need to get cost outlays rebated to cash-starved start-up much faster - State putting in funds through El, then withholding them through

Revenue.

Approach differently between SME and MNC.

Simplify the documentation.

Simpler application and submission of reports.

Provide a framework for recording employee-eligible work time.

All time spent on new products should qualify for R\&D.

Clearly specify cost categories that are claimable.

Would like to see it more streamlined and simplified, particularly for Irish SMEs.

Revenue need to be more supportive. They are too difficult to deal with.

1. Extend the claim period.

2. Further promotion (e.g. through IRDG events).

A template for calculation would be a huge help and should be 'auditable' by Revenue, if they wish to query any amounts included as 'qualifying expenditure'.

Very clear guidelines of what can and cannot be included (with specific examples).

Make it simpler. Revenue have a very narrow view as to what constitutes R\&D.

A little more flexible.

Simplify the claim approach and lessen the burden on companies.

Broaden the scope of qualifying work.

Increase the rate and make it easier on the internal administration.

Better detail around what is considered as R\&D. The majority of multinationals in Ireland are doing Redesign and Development and should not be considered for R\&D tax credits. This is the reason why multinationals provide large reports to try and justify that the work is R\&D.

Make it easier to understand.

An online application claim, direct to revenue - self-assessment, like the ROS process.

Simplify the process. R\&D tax credits are being given on activities that companies are going to engage in anyway. Change the incentive to reduce companies' direct R\&D costs at source, such as reduced salary costs to companies (e.g. PRSI, PAYE rebates). That way, the tax credit is seen directly within R\&D budgets and not applied outside it, to overall business costs. When the tax credit benefit is seen directly within R\&D budgets, then overall R\&D activity is more likely to increase.

All essential elements of R\&D activities to be claimable. Currently, many R\&D support activities are deemed ineligible. This creates grey areas and high administration and risk.

Streamline administration and get rid of timesheets. The proof required for an innovation should be based on laboratory based-study and incremental innovation

Clearer Revenue guidance.

Simplify and reduce the workload, especially for small companies.

Give very clear guidelines and outline examples case studies, etc.

Time to process the credit should be accelerated for start-ups, as the cash flow is critical for small companies. 


\section{DISCUSSION}

\section{Business expenditure on R\&D (BERD)}

The recent CSO report on business expenditure on R\&D (CSO, 2017) shows that enterprises employing 250+ people had the greatest share of R\&D expenditure in 2015 , with $55 \%$ of all actual expenditure. This accounted for $€ 1.2 \mathrm{bn}$ of the total spend. Small enterprises with fewer than 50 people spent almost $€ 502 \mathrm{~m}$ on R\&D in 2015 , which accounted for more than $22 \%$ of the spend. Medium-sized enterprises employing between 50 and 249 people spent just over $€ 503 \mathrm{~m}$ in the same period, which represented $23 \%$ of the total spend. The breakdown of R\&D expenditure in 2016 by employment size class shows a similar distribution to that of 2015, with small enterprises estimating that they would spend approximately $€ 580 \mathrm{~m}$. Medium enterprises forecast a spend of $€ 522 \mathrm{~m}$. Large enterprises estimated that they would spend nearly $€ 1.2 \mathrm{bn}$ in 2016 (see Table 1 for more information).

Foreign-owned enterprises accounted for $64 \%$ of all R\&D expenditure, with just over $€ 1$.3bn being spent on current expenditure, thus representing $93 \%$ of all their R\&D expenditure. The remaining $7 \%$ or $€ 98 \mathrm{~m}$ was spent on capital expenditure. Irish-owned enterprises, in comparison, spent more than $€ 800 \mathrm{~m}$ on R\&D, with current expenditure at $€ 751 \mathrm{~m}$, accounting for nearly $93 \%$ of this expenditure. The remaining $7 \%$ or $€ 59 \mathrm{~m}$ was spent on capital expenditure (CSO, 2017).

Seventy-two percent of the respondents in this survey (86 out of 122 companies) were from Irish-owned firms. Of the remaining $28 \%$ from this study, 34 were foreign-owned companies; and a breakdown of 29 of these companies showed that the majority were US-owned. The high number of US firms presented in this work is indicative of the overall Irish economy, which has more than 700 such companies operating in Ireland, equating to 150,000 people directly and a further 100,000 indirectly employed.

\section{The influence of the R\&D tax credit on BERD}

The information presented in Table 2 (where applicable) is graphically represented in Figure 1. As shown, there has been an $€ 897 \mathrm{~m}$ increase in BERD within this period. Although not included in the graph, the BERD figures for both 2015 and 2016 were $€ 2233 \mathrm{~m}$ and $€ 2293 \mathrm{~m}$, respectively. From this data, it can be reasonable postulated that the main driver of growth has been attributed to the introduction of the credit. Other factors include the increase in government R\&D expenditure into the third-level sector, the growth of information and communications technology (ICT) and the medical technology and pharmaceutical sectors, as well as the availability of potential grants (pending independent review) from the European Union (EU), Enterprise Ireland, and Science Foundation Ireland. Interestingly, 376 of the companies availing of the payable credit in 2011 were profit-making, according to their accounts (Department of Finance, 2013).

Looking at the information presented in Figure 1, there has been an eightfold increase in the amount of credit claimed in 2004, compared to 2014. What is also of interest is that the size of the claims is increasing but the number of claims is stabilising, which may be due to:

1. More growth in R\&D activities.

2. The interpretations of companies regarding what can qualify, especially in the development phase.

3. An increase in the start-up community whose members are in the early phases of growth in R\&D.

4. Companies no longer availing of the credit.

5. Companies which have resolved their technology uncertainties and can no longer qualify.

This increase from 75 million in claims in 2004 to 553 million in 2014 has had a significant impact on the tax take.

In its 2016 report (Economic Evaluation of the R\&D Tax Credit), the Department of Finance evaluated the R\&D tax credit scheme and noted the value of the outstanding credits in 2014 and the effects of its associated size of this future liability to the Exchequer (Department of Finance, 2016). However, the department also acknowledges that many reviews of tax incentives from international organisations suggest that a cash refund, in the form of a repayable credit option, is good for new firms. The department's own findings have shown that such an approach can result in notable deadweight. It goes on to say that this does not make a repayable credit a bad thing in and of itself (e.g. it protects R\&D spending during a recession) and suggests that careful design is needed to prevent a large cost to the Exchequer, with little additional R\&D from young or other firms to show for it. Considering the above, and briefly bearing in mind all the positive effects of the R\&D tax credit as discussed in the introduction, fundamentally, the interpretation of what $R \& D$ is and what can qualify varies between sectors. Thus, in the principle 
of the law, companies must work within the set guidelines of Revenue. It is important to remember that since 2016 , companies have been required to allow the qualifying $R \& D$ to be examined by an independent academic assessor appointed by the Revenue Commissioners.

\section{An assessment of the awareness of the R\&D tax credit scheme}

Ireland's tax incentives for R\&D activity have improved considerably over the past decade but the offerings of the country's main competitors have also been enhanced (IBEC, 2013). In conjunction with the IBEC survey completed in 2013 by 247 firms, and the information gathered by this survey (122 respondents/firms), a comprehensive understanding of companies' views regarding the tax credit scheme has emerged from the data.

When asked if there was an awareness of the R\&D tax credit within their organisation, $95 \%$ of respondents said 'Yes'. This is an interesting finding, considering that IBEC, in 2013, found that almost one in three firms cited poor awareness of the credit as a reason for not using it (IBEC, 2013). This would suggest that there has been a growth in the awareness of the scheme, which is an important indicator of the R\&D incentives available to the business community. However, if a lack of awareness is one of the factors in failure to use the credit, this may contribute to the plateau that has emerged, as presented in Figure 1.

Expanding on this 95\% response in relation to awareness, when asked if the R\&D tax credit was adequately promoted, $47 \%$ said 'Yes' and 32\% said 'No'. Even though such a high percentage are aware of the credit, one-third of the participants stated there is a lack of promotion. This may be due, in part, to internal company policies or a lack of targeted marketing. A breakdown of the company size and response is presented in Table 3. It is of interest to note there is a relatively even split between the Yes and No responses for the smaller-sized companies; and as the company size increases, the \% value for Yes also increases.

When asked if they had used or continued to use the R\&D tax credits, one-third (31\%) of respondents confirmed that they had not used the credit (the breakdown of company size is shown in Table 4). For the 59\% of companies that said 'Yes', a large majority were from the SME and multinational sector, with a balanced mix of Yes and No responses from the start-up and small enterprise companies. While the IBEC survey cites poor awareness as a reason for not taking up the scheme, it is not an influencing factor in this survey. One probable solution is the increased awareness of the credit over recent years, as well as the growth in the start-up sector. However, when asked if the R\&D tax scheme has been adequately promoted, only 47\% said 'Yes', even though 95\% of responders were aware of it. This is concerning factor and introduces doubt into the process. Possible reasons why companies are not availing of the credit are discussed later.

\section{The impact of job creation resulting from the $R \& D$ tax credit scheme}

It is often (unjustly) said that tax is the only reason why foreign companies set up Ireland, but with investment in education, and a strong IDA presence and Enterprise Ireland support, there is a growth in industry and entrepreneurial spirit. To back up this view, IBEC, from its 2013 survey of 247 companies, found that $42 \%$ of firms ranked the availability of qualified staff as the most important factor in their decision to locate R\&D investment in Ireland. To put this into perspective, in 2015 , enterprises reported that over $€ 1.3 \mathrm{bn}$ was spent on labour costs, which accounted for $61 \%$ of all R\&D expenditure (CSO, 2017). In relation to tax incentives, among $24 \%$ of the companies surveyed by IBEC, this was ranked the second most important issue (IBEC, 2013).

In relation to job creation, the overall findings from this work found that $35 \%$ of the people surveyed stated that the R\&D tax credit has helped create jobs, whereas, $44 \%$ of the responders noted that it had not created jobs within their organisation. A breakdown in relation to company size regarding job creation is presented in Table 5 . Taking a deeper dive into the findings and focusing on both manufacturing and R\&D only based companies, the following results are presented;

$>$ Manufacturing based companies [n=37], $41 \%$ of the respondents said that the credit has helped in the creation of jobs, while $35 \%$ said that it had not helped.

$>$ R\&D based companies [ $n=60], 32 \%$ said 'Yes' and $47 \%$ said 'No'.

What can be taken from the analysis is that there is a clear indication that companies acknowledge that the tax credit is a factor in job creation. This is an important indicator for the success of the scheme, as job creation from new innovations is a key driver in a knowledge economy. Similar findings were also found by IBEC (Table 6), which confirmed that the R\&D tax credit is important to employment growth in Ireland: $62 \%$ of firms said that the credit was important to their firm, creating new jobs, while a further $67 \%$ said it was important to the retention of jobs in the 
country. Evidence of this is presented in Table 6, which shows that there was an increase in R\&D tax credit-related jobs from 279 in 2003 to 2523 in 2011.

\section{Reasons for companies not claiming the credit}

It may be counterproductive to think why a company would not claim the R\&D tax credit (a $25 \%$ rebate on qualifying expenditure), but there are genuine practicalities why this may be the case. The guidelines set out by Revenue are very specific in their terminology but leave certain interpretations as to what can be deemed as qualifying. This puts the onus on the company to prove, in an audit, that qualifying activities took place; and the company must maintain these records for four years. Listed below are some of the reasons given by the $25 \%$ of companies in the IBEC survey for not availing of the credit. The SMEs in the sample were less likely to use the credit, with $41 \%$ reporting that they had not done so (IBEC, 2013):

$>$ The major deterrent for R\&D active companies to using the credit is its administrative burden. About $37 \%$ of companies cited this as a barrier to the credit.

$>$ Almost one in three firms cited poor awareness of the credit as a reason for not using it.

D further $26 \%$ of firms reported that their lack of supporting documentation was a barrier to take-up.

The information collated from the present work is presented in Table 7 and gives more of an insight into the motives behind companies failing to claim the credit. The main reason stated was administration, which very much corresponds with the results of the IBEC survey. Some interesting comments emerged from the present study, highlighting the difficulties associated with the R\&D tax credit scheme. There is confusion regarding the process and companies rely for the most part on professional services firms to assess and prepare the qualifying activities and financial activities. This has also created challenges and results in a lack of certainty in relation to the credit. For companies relying on the credit, especially start-ups, this can slow innovation due to financial reasons. Of interest, one responder made a very valid and important comment: 'We don't innovate because there's a tax credit - we do it because we must.' This opens an interesting debate, in that, if the credit did not exist would there still be innovation? A key motive of a company is to survive and grow. Therefore, would having no credit available make the company more efficient and less risk-adverse? Or, if a company were to avail of the credit, the risky projects that may not have been considered for financial reasons might be sanctioned on the basis that there are uncertainties associated with the work. This mindset to innovate feeds very much into the previous findings by the Department of Finance, whereby roughly $40 \%$ of the R\&D observed over the period would have occurred anyway, that is, in the absence of the tax credit.

In acknowledgment to the barriers that are present, the Department of Finance (2016), in its R\&D tax credit evaluation, stated:

[W]e did not find evidence that the tax credit scheme is effective in encouraging R\&D in younger firms, which suggests other barriers to conducting R\&D for this type of firm should be examined in greater detail, and public policy tailored appropriately. On the other hand, the scheme appears to be effective for older firms, so a possible policy response is simply to adopt a "wait and see" approach. If market forces allow a firm to grow to a sufficient stage of development, then the tax credit (as it stands) can assist that firm to perform additional R\&D. It may give rise to further inefficiencies to try to target inexperienced firms via a tax credit policy that specifically differentiates firms with respect to age.

\section{Industry recommendation to improve the $R \& D$ tax credit process}

IBEC has found that while most companies are pleased with the administration of the scheme, a significant percentage have experienced difficulties. With the increase in companies availing of the credit, Revenue has become more active and most companies now (1) receive a revenue questionnaire, to clarify some point regarding what they are claiming to justify the credit; (2) undergo a desk audit regarding their financial activities and (3) undergo a full physical audit, with a technical expert on their premises. These activities can be a deterrent to companies who wish to avail of the credit. IBEC has collected the following findings:

$>$ A number of start-up firms were unsure of the potential barriers they might face and experienced capacity issues in undertaking R\&D.

$>$ Some firms that did participate in R\&D activities felt that these activities fell outside the scope of the existing credit. This was particularly true of firms in the IT sector.

$>$ Several firms did not participate in R\&D activities. 
Several firms were investigating the implications of the credit and had yet to decide on its applicability.

As a key part of the present work, the voice of the industry was a requirement in addressing the tax incentives available to them. There is a lot of promotion regarding the R\&D tax credit; but, as previously outlined, a lot of work is needed to avail of the credit and the uncertainty which surrounds each claim is a key risk. As revealed in Table 8 , there are very strong recommendations to Revenue/Government regarding the process, considering the burden of administration and professional costs and other reasons not to avail of the credit.

\section{CONCLUSION}

In 2015, 1,900 R\&D-active firms were registered in Ireland, of which 694 (or 37\%) had R\&D spend of under $€ 100,000$, which was the most popular spend category for manufacturing firms. Therefore, with the establishment of strong reputations in the manufacturing sector, as well as the formation of clusters, the emergence of a strong multidisciplinary approach has lent itself to unpresented growth in innovation within the economy. This is a great indication of the importance of R\&D, which lends itself to manufacturing and further innovations. Thus, at a macro level, this is a real indicator of an innovation-led economy.

Looking at the government R\&D tax supports that are used to promote innovation, the Department of Finance has calculated that for each euro in foregone revenue, an additional $€ 2.40$ is generated in R\&D. From an IBEC study involving 247 firms, comments on the impact of the scheme were almost wholly positive and most firms cited its presence as a key element in their decision to invest in Ireland. But, the tax credit scheme is not without its challenges and it is important to note that, after 13 years in existence, there is still confusion surrounding it; and this will have a major influence on the promotion and growth of innovation.

Some of the key findings from this study are:

$>\quad 95 \%$ of the respondents said they were aware of the R\&D tax credit.

$>\quad 73 \%$ said they would recommend the R\&D tax credit to a colleague.

$>47 \%$ said the R\&D tax credit was adequately promoted.

$>32 \%$ said the R\&D tax credit was not adequately promoted.

$>35 \%$ said that the R\&D tax credit has helped create jobs, and $44 \%$ saying that it had not created jobs in the organisation.

$>$ Administration was the main reason given by companies for not claiming the R\&D tax credit.

$>51 \%$ said that the R\&D tax credit had not been a strong factor in driving the company's innovation, with $25 \%$ saying that it was an important factor.

Although there is substantial evidence that R\&D tax incentives increase the amount of R\&D investment, the estimates from literature vary considerably. In addition, R\&D tax incentives may induce R\&D investment to be shifted between different locations instead of increasing the overall level of local investment. R\&D tax incentives have now become a popular innovation policy instrument and competition is growing between countries to attract investment. These incentives are important for a small and open economy like Ireland, as it maintains a balanced playing field for foreign direct investment inflows and facilitates knowledge transfer from innovative multinationals, with a potential to create cluster spillovers.

\section{References}

Atkinson, R.D. and Andes, S. (2011). 'Patent boxes: innovation in tax policy and tax policy for innovation'. https://www.itif.org/files/2011-patent-box-final.pdf [Accessed April 15 ${ }^{\text {th }}, 2018$ ].

Castellacci, F. and Lie, C.M. (2015). 'Do the effects of R\&D tax credits vary across industries? A metaregression analysis'. Research Policy, 44, 819832.
Central Stastistics Office (2017). http://www.cso.ie/en/ releasesandpublications/er/berd/businessexpenditureonresearchdevelopment2015-2016/ [Accessed April 15 $\left.{ }^{\text {th }}, 2018\right]$.

Czarnitzki, D., Hanel, P. and Rosa, J.M. (2011). 'Evaluating the Impact of R\&D tax credits on innovation: A micro econometric study on Canadian firms', Research Policy, 40: 2, 217-229. 
Busom, I., Corchuelo, B. and Martinez-Ros, E. (2014). 'Tax incentives or subsidies for business R\&D?' Small Business Economics, 43: 3, 571-596.

Department of Finance (2013). Review of Ireland's Research and Development (R\&D) Tax credit 2013. http://budget.gov.ie/Budgets/2014/Documents/ Department\%20of\%20Finance\%20Review\%20 of $\% 20 R \& D \% 20$ Tax $\% 20$ Credit $\% 202013 . p d f$ [Accessed 30 April 2018].

Department of Finance (2016). Economic Evaluation of the R\&D ax Credit.

http://igees.gov.ie/wp-content/uploads/2014/01/R-andD-Credit-Evaluation-2016.pdf [Accessed 15 May 15 2018].

Evers, L. (2014). 'Intellectual property (IP) box regimes (tax planning, effective tax burdens and tax policy options)', Unpublished PhD, Mannheim University.

Gao, L., Yang, L. and Zhang, J. (2016). 'Corporate patents, R\&D success, and tax avoidance'. Review of Quantitative Finance \& Accounting, 47: 4, 10631096.

Hall, B. and Van Reenen. J. (2000). 'How effective are fiscal incentives for R\&D? A review of the evidence'. Research Policy 29: 4-5), 449-469.

IBEC (2013). IBEC Submission to the Department of Finance Review of the R\&D Tax Credit Scheme. http://taxpolicy.gov.ie/wp-content/uploads/2013/10/ IBEC.pdf [Accessed 8 May 2018].

Irish Tax Institute (2015). Knowledge Development Box. https://taxinstitute.ie/wp-content/uploads/2018/01/ Institute-Submission-on-Knowledge-Development-
Box.pdf [Accessed 4 November 2016].

Jaffe, A. (1996). Economic analysis of research spill overs implications for the advanced technology program. https://ntrl.ntis.gov/NTRL/dashboard/ searchResults/titleDetail/PB2007105379.xhtml [Accessed 4 May 2018].

Jones, C.L., Rogers, A.A. and Smyth, D.J. (2016). 'Should the United States enact a Patent Box?' Tax Adviser. https://www.thetaxadviser.com/ issues/2016/nov/should-us-enact-patent-box.html [Accessed 5 May 2018].

Lester, J. (2012). 'benefit-cost analysis of R\&D support programs', Canadian Tax Journal, 60: 4, 793-836.

Martin, S. and Scott. J.T. (2000). 'The nature of innovation market failure and the design of public support for private innovation'. Research Policy, 29: 45, 437-447.

OECD (2010). R\&D Tax Incentives: Rationale, Design, Evaluation. Paris: OECD.

Straathof, B., E. Gaillard Ladinska, H.L.M. Kox and R. Mocking (2014), "A study on R\&D tax incentives: Final Report”, EU Taxation Paper No. 52 (2014).

Tyson, L. and Linden, G. (2012). The Corporate R\&D Tax Credit and U.S. Innovation and Competitiveness. Gauging the Economic and Fiscal Effectiveness of the Credit.

https://www.americanprogress.org/issues/economy/ reports/2012/01/06/10975/the-corporate-rd-taxcredit-and-u-s-innovation-and-competitiveness/ [Accessed April 28th, 2018] 